\title{
Strengthening of Social Cohesion in the Practice of Liké Geleng among the Aneuk Jamè Ethnic Group in Aceh
}

\author{
Bustami Abubakar, ${ }^{1 *}$ Ikhwan Ikhwan, ${ }^{1}$ Sugiarso Sugiarso ${ }^{2}$ \\ ${ }^{1}$ Faculty of Adab dan Humanities, Universitas Islam Negeri Ar-Raniry Banda Aceh - \\ Indonesia, ${ }^{2}$ Faculty of Social and Political Sciences, Universitas Islam Negeri Walisongo, \\ Semarang - Indonesia
}

\begin{abstract}
Liké geleng is a practice of traditions among the Aneuk Jamè ethnic group in Aceh. The implementation of Liké geleng tradition consisted of many traditions included the commemoration of Maulid Nabi. This study discusses the implementation of Liké geleng and its relationship with strengthening social cohesion among the Aneuk Jamè ethnic group in Kampung Balai, Samadua, South Aceh. This research objective is to explore the traditions within the Liké geleng and how the implementation of the traditions among the Aneuk Jamè ethnic community. The informants consisted of religious leaders, traditional leaders, women leaders, and the community involved in carrying out the Maulid Nabi memorial in the village. Applying the method of qualitative research, the results of the study showed that the implementation of Likégeleng among the Aneuk Jamè ethnic group as an activity in commemoration of the Maulid Nabi Muhammad is an activity that can strengthen social cohesion in the community. This is indicated by the development of closer friendship and kinship, increasingly frequent social interactions, and stronger cooperation between communities. This result proved that tradition may strengthen social cohesion by doing the tradition together.
\end{abstract}

Liké geleng merupakan praktek tradisi di kalangan suku Anek Jame di Aceh. Pelaksanaan tradisi like geleng terdiri atas banyak tradisi termasuk peringatan Maulid Nabi. Kajian ini membahas tentang pelaksanaan Liké geleng dan hubungannya dengan penguatan kohesi sosial di kalangan suku Aneuk Jamè di Kampung Balai, Samadua, Aceh Selatan. Tujuan penelitian adalah menemukan keterkaitan antara pelaksanaan Liké geleng dengan penguatan kohesi sosial masyarakat suku Aneuk Jamè. Penelitian ini menggunakan pendekatan kualitatif. Informan terdiri dari tokoh agama, tokoh adat, tokoh perempuan, dan masyarakat yang terlibat dalam pelaksanaan peringatan Maulid Nabi di kampung tersebut. Hasil penelitian menyimpulkan bahwa penyelenggaraan Liké geleng di kalangan suku Aneuk Jamè sebagai satu kegiatan dalam rangka memperingati Maulid Nabi Muhammad merupakan suatu kegiatan yang dapat memperkuat kohesi sosial di antara masyarakat. Hal ini ditandai dengan terbangunnya hubungan persaudaraan dan kekerabatan yang kian erat, interaksi sosial yang semakin kerap, dan kerjasama antar masyarakat yang semakin kuat.

Keywords: Liké geleng; Aneuk Jamè; social cohesion

*Corresponding Author: Bustami Abubakar (bustami.abubakar@ar-raniry.ac.id), Jl. Syeikh Abdul Rauf, Kopelma Darussalam, Banda Aceh 23111, Indonesia. 


\section{Introduction}

Aneuk Jamè, is one of some other ethnics living in Aceh, like Acehnese, Gayo, Tamiang, Alas, Kluet, Devayan, and Singkil (Abubakar 2012). Almost all ethnic groups are Muslims. Therefore, in all regions in Aceh Province, the momentum of the birth of the Prophet Muhammad SAW -as the bearer of Islamic teachings - is celebrated lively every year, following the traditions and cultural peculiarities of each ethnic group. Annemarie Schimmel in Nurdin (2016) states that the commemorations of the Prophet's birthday are a form of expression of love and respect for Muslims to their prophet as their role model, Muhammad SAW. Through these celebrations, Muslims can find out all things related to the personality, sayings and views of the Prophet Muhammad, so that the example he leaves can be followed properly and correctly.

In Aceh, the commemoration of the Prophet's birthday is usually in the form of a feast called khanduri molôd. It can be carried out over 3 (three) months, namely from 12 Rabiul Awal, Rabiul Akhir, and Jumadil Awal. For that reason, the names of the months in Acehnese are consist of three months of molôd. Hurgronje (1996), wrote the names of the molôd months as follows: Rabi' al-awwal = mo'lot (from Mawlid, commemorating the birthday of the Prophet Muhammad); Rabi' al-Akhir = adoe molot (brother molot, because the birthday of the Prophet was also in that month); and Jumada 'al-awwal = mo'lot seuneulheuh (the end of molot, because this month is still used to commemorate the birth of Muhammad. Now, the Acehnese call the three months of molôd by the names: molôd awai, molôd teungoh, and molôd akhé/seuneulheuh.

Various activities were held to welcome and celebrate the Prophet's birthday. All elements of society participate and carry out their respective activities. For most people in Aceh, how and whatever activities are carried out, the climax of the series of activities is the feast during the day, followed by religious lectures at night. This feast is what is called khanduri molốd (feast of maulid).

One of the ethnic groups in Aceh and has a unique and distinctive tradition of commemorating the birthday of the Prophet Muhammad SAW is the Aneuk Jamè ethnic group. Therefore, this research aims to examine the implementation of the Prophet's birthday commemoration in the form of Liké geleng among the Aneuk Jamè ethnic group and its relationship with social cohesion.

The concept of social cohesion originates from Emile Durkheim's thesis. According to him, there is mechanical solidarity in society, which is indicated by the presence of strong actors. Besides, there is also organic solidarity which is indicated by the interdependence of individuals so that social cohesion will be formed by itself (Soekanto 2005). The social cohesion in society, both between individuals and between groups, is characterized by social cohesion (Mubyarto 1993).

The Council of Europe (2004) defines social cohesion as a society's ability to guarantee the welfare of its members, reduce disparity, and avoid polarization. The manifestation of social cohesion is indicated by a community that supports each other to achieve common goals democratically. Social cohesion is characterized 
by balancing the effort to achieve a level of social stability. Usman Pelly in Anriani (Anriani et al. 2018) describes social cohesion among groups and ethnic groups as a social condition that reflects harmony, namely, cooperation, accommodation, acculturation, and assimilation. One of the essential factors that influence the development of social cohesion is cooperation among groups in society.

Social cohesion refers to the extent of connectedness and solidarity between groups in society. It identifies two main dimensions: a sense of community ownership and the relationships among members within the community itself (Manca 2014).

According to Friedkin (2004), the indicators of social cohesion at the individual level can be examined through 2 (two) aspects, namely: first, the attitudes of individuals in a group/society, including their desire to remain in a group, identification or their loyalty to the group, and their attitude towards the group or group members; second, individual membership behavior such as their decision to decide, weaken, maintain or strengthen their membership or participation in the group, their vulnerability to interpersonal influence, and commitment and attachment to the group.

Social cohesion is built and bonded through the community's various activities, including religious activities, especially ceremonial and celebratory ceremonies. The variety of activities carried out by religious followers as an implementation of religious teachings that are understood or taught has made religion change its form from text in the holy book to observable activities. This fact was discovered by Durkheim that later became foundation of view that religion is an inseparable part of social activity. According to Abdullah (2009), Durkheim's approach has become a formula for the hypothesis that religion is the primary basis of integration and social cohesion.

The Aneuk Jamè ethnic group inhabits the southern coast of Aceh Province and a small part of them are on the West coast. They are scattered in all sub-districts in the districts of South Aceh and Aceh Barat Daya, although in terms of numbers and percentages, the distribution is not evenly distributed across all sub-districts. The sub-districts that are quite dominant in the Aneuk Jamè ethnic group are Tapak Tuan, Labuhan Haji Barat, Labuhan Haji Timur, Labuhan Haji Tengah, and Samadua.

Judging from the laqab (name) of the ethnic group, it is clear that the Aneuk Jamè ethnic group is not a native of Aceh, but it is an immigrant ethnic group. The word "Aneuk Jamè" in Acehnese means "guest child". However, there are not many references to the origins of Aneuk Jamè. Therefore, social scientists try to write about the origin of this ethnic group, only relate its existence to the history of the arrival of the Minangkabau people to the west coast of Aceh. As migrants, the Minangkabau people acculturate with local residents. This acculturation gave birth to the Aneuk Jamè ethnic group, namely mixing the Minangkabau and the Acehnese (Sufi et al. 1998).

The relationship between the Aneuk Jamè ethnic group in Aceh and the Minang ethnic group in West Sumatra is increasingly clear when viewed from a cultural aspect: language. The Aneuk Jamè ethnic group uses the Jamè language as their mother tongue. It is assumed 
that the Jamè language originated from the Minang language, especially if we look at the vocabulary used. Besides, absorption and/or influence from the Acehnese language also appears in Jamè language. It is one of the cultural contact expressions that causes cultural acculturation, which is reflected in language.

This research was conducted in Kampung Balai, Kasik Putih, Samadua, South Aceh. Kampung Balai consists of two hamlets, namely Dusun Bahagia and Dusun Mulia. From the aspect of livelihood, most of the population work as traders, followed by farmers, laborers, and civil servants. The primary natural resource that the community can explore is excavation, such as gravel. Besides, most of the inhabitants of this village develop home industries, such as sewing, embroidery, and furniture businesses.

This research uses a qualitative approach The data was collected using observation, interviews, and literature review. Observation is used to observe and hear to understand, seek answers and evidence for the phenomena being studied, in the form of certain behaviors, events, circumstances, objects and symbols. The observed phenomena are then recorded and recorded to discover data analysis (Suprayogo and Tobroni 2001). The interview is used to determine the informants' opinions, views, and responses on matters related to the research issue. The interview method used is the unstructured interview method, namely interviews that provide flexibility for researchers to track various aspects and directions to obtain the necessary information (Faisal 2003). The choice of this method is because it provides a large enough space for researchers to explore data compared to the structured interview method (Fontana and Frey 1994).
The selection of informants was carried out using the purposive sampling technique. The informants consisted of religious leaders, traditional leaders, women leaders, and the community who were involved in the implementation of Maulid Nabi in the village. The research objective was to find a link between the implementation of Liké geleng and the strengthening of the social cohesion of the Aneuk Jamè ethnic community.

Many researchers have also studied the tradition of commemorating the Maulid Nabi in Aceh (Abubakar 2016; Fakhrurrazi 2012; Ibrahim 2014; Nurdin 2016). Fakhrurrazi researched the acculturation of Aceh and Arabic culture in Maulid feasts. He found that maulid feast, which is now being celebrated throughout Aceh, is a form of transformation of Arabic Islamic culture with Acehnese Hindu culture. After Islam entered and developed in Aceh brought by people from the Arabian Peninsula, there was cultural acculturation. One of them is the tradition of celebrating Maulid Nabi by reading the Barzanji (Fakhrurrazi 2012).

The study of Abubakar (2016) focused on the celebration of the maulid feast as a form of Islamic interaction with local culture. Islamic values in the feast of the maulid tradition can be a means of preaching and strengthening Islamic brotherhood through meals and donations to the orphan. Research conducted by Nurdin (2016) also shows the similarity of integration of religion and culture, especially in dishes provided during the feast of mauled, which included idang meulapeh (multilayered dish). The integration of religion and socio-cultural activities occurs inherently and has been in effect for a long time in Aceh. This integration is 
reflected in the expression: "hukom ngon adat lagee zat ngon sifeut", which means law (religious law) and customs are like substance (God) and His nature (Ibrahim 2014; Zainuddin 2007). In Nurdin's observation (2016), this expression implies that Islam has become a world view in the Acehnese society's systems, institutions, and social structures. Furthermore, Islam has also become the way of life that has crystallized in Acehnese customs and culture.

Other researchers also discussed maulid in another part of Indonesia, such as in Java and Sulawesi. The integration of Islamic teachings and cultural elements in the commemoration of Maulid Nabi has also occurred in various regions in Indonesia. For Mlangi Hamlet, Gamping District, Sleman, Yogyakarta, the ritual of maulid started by the men read prayers in the mosque. The women are busy making blessings and food, the peak of the festivities occurred at night, during the competition of shalawat whose held by students from various Islamic boarding schools in the area (Nadia 2016).

The people of Cikoang, Takalar, South Sulawesi is known as maudu 'lompoa. Maulid carried out in 2 stages, namely the preparation stage and the implementation stage. The preparatory stage begins with self-purification by taking a Safar bath on $10^{\text {th }}$ day of Safar. The following process in this preparation period provides 4 (four) main ingredients as symbols of Islam's 4 (four) components. The four main ingredients are rice, chicken, coconut, and eggs. The components are implementing the teaching concept of Nur Muhammad brought by Sayyid Jalaluddin, a scholar from Aceh (Yuliana and Soedarsono 2004). The tradition of maudu 'lompoa is based on the concept of Sufism. In the science of Sufism, the Prophet Muhammad is believed to have been at the level of the highest state, namely ma'rifat (Sila 2014). The preparation period can be quite long from the celebration period because the various needs presented at the peak event are provided (Hendra et al. 2019). The peak of the maudu Iompoa celebration is held at the end of the month of Rabiul Awal. Types of food that have been prepared since the month of Safar are put on a decorative vessel called julung-julung. After reading the Prophet's prayer (rate), the people fought over the contents of the julung-julung. They ended the celebration by taking a bath on the Cikoang river to express gratitude for the abundance of sustenance (Alsair 2019).

Andri Maijar's study (2018) focused on the Bungo Lado tradition displayed at the Prophet Muhammad SAW's birthday event in Padang Pariaman as one of the community's representations of Islamic culture. Bungo lado (chili flower) is an ornamental tree whose leaves are made of money, so it is called a money tree. It is one of the people's euphoria in welcoming the birthday of the Prophet Muhammad SAW. In its implementation, each community group competes to donate half of their income by placing or decorating the money on a tree branch as a form of happiness (Maijar 2018). Etymologically, Bungo Lado comes from the Minang language, which means flower, lado means pepper or chilli. In denotation, it means chilli flowers. But the connotation of Bungo Lado is to mean "money tree". The ritual or tradition of celebrating the Prophet's birthday is done by making a kind of ornamental tree decorated with toy banknotes (Reporter 2019). 
Zulfa Jamalie's research (2014) examines the acculturation and transformation of values in the Baayun Maulid tradition of the Banjar community. The history of this tradition stems from the maayun ceremony for children of the Dayak Kalimantan people to give blessings, give names, convey prayers of safety, and a sign of gratitude for the birth of a child. Along with the entry and development of Islam in this area, Baayun Anak, underwent acculturation to Baayun Maulid. The child is swung and recited by the Quran, the maulid verses, and prayers. Local traditions and religious teachings have harmoniously united in the Baayun Maulid activities, which are a sign of gratitude for the birth of a child and a memorial and respect for the Prophet Muhammad's birthday.

Unlike previous studies on the commemoration of Maulid Nabi in Aceh, this study concentrated more on social cohesion in implementing the maulid feast. Therefore, this research aims to examine the implementation of Maulid Nabi commemoration in Liké geleng among the Aneuk Jamè ethnic group and its relationship with social cohesion.

\section{Implementation of Maulid}

Among the Aneuk Jamè people, there are two patterns of celebrating the maulid. The first pattern is to hold a religious lecture as the highlight of the event. The second pattern is by holding a Liké geleng. If the first pattern is carried out, the second pattern is abandoned. Vice versa. During the armed conflict in Aceh, the Aneuk Jamè people prefer the first pattern to commemorate the birth of the Prophet Muhammad SAW. It is closely related to the safety and security aspects of the community.
This situation caused the community not to have the courage to carry out activities late into the night, especially by presenting other people outside their village.

The holding of the maulid with the pattern of religious lectures is not something new, unique, and interesting to study academically. There are relatively no differences in its administration or other matters related to it than other regions other ethnicities living in Aceh with this pattern. Therefore, this research focuses on implementing the second maulid, namely by holding Liké geleng. In addition to pointing out specific and unique things in its implementation that cause it to be different from the performance of conformance in other regions and ethnicities, this effort is also intended to preserve and disseminate local traditions as one cultural asset.

\section{Some Preparation for Like Geleng Tradition}

\section{Forum Kampuang as the Decision Making of Liké Geleng}

Kampung Balai's chief, Syahril (56 years old), explains that the first step taken before implementing the maulid celebration is to hold a forum at the meunasah ${ }^{1}$ or mosque. This forum

\footnotetext{
${ }^{1}$ Meunasah derives from Arabic: madrasah, which is a religious institution at the village level led by Imam Meunasah. Every village in Aceh has, at least, one meunasah which functions as a place for praying, studying the Koran and religious studying, organizing village meetings, and carrying out Islamic holidays. In fact, before the development of village administration management as it is now, the meunasah also functioned as a place for the implementation of village administration. In the past, the meunasah also functioned as a place to stay for village youths and male guests who spent the night in the village (Ibrahim 2014; Ismail 2007).
} 
is limited in nature, attended only by certain circles. The forum is chaired by the village head (geuchik) and attended by traditional leaders, religious leaders and community leaders. In this deliberation, it is decided whether or not a maulid celebration will be held. If it is carried out, it will also be agreed whether by holding religious lectures or by holding Liké geleng.

Suppose the forum participants decide to implement it and by holding a Liké geleng. Case, it is also agreed upon the timing of the implementation and which mosque community will be invited to participate in the Liké geleng. Usually, the mosque is adjusted or balanced -in terms of population and village coverage- with the inviting village. It is related to the number of Liké geleng participants who will attend, which is directly proportional to the number of jamba and other dishes that the host must provide. The villages invited to participate in the Liké geleng are usually located in one sub-district, but sometimes villages from different sub-districts also participate.

After this limited forum agreed one decision, on another occasion the geuchik invited all the villagers to the meunasah or mosque to ask for their approval and support for the decisions of the previous forum. A few days after the meeting, the geuchik, accompanied by several community leaders, went to the village to be invited to submit a "proposal". it is called to propose because of its similarity with married procession. The invitation normally delivered 15 days before the festivities to provide the amount of time for the invited to practice Liké geleng (Interview of Syahril [56 years old] chief of Kampung Balai, Samadua Subdistrict, South Aceh).
After holding a meeting with the community on the appointed day, the invited village will make a return visit to the inviting geuchik to provide answers to the invitation that had been submitted. On the other hand, the inviting geuchik accompanied by tuha peut and community leaders have been waiting for the presence guests at' presence geuchik house. The bati (special container use for special occasion, it is an open-up container, usually made of brass) containing betel nut and betel leaves that was given by the inviting geuchik did not forget to return it. Once the proposal was accepted, the number of Liké geleng participants from the guest village is also agreed. This relates to the amount of jamba the host must provide. However, if the invited party reject, the village that wants to hold the maulid will immediately consult again to determine another village to be invited (Interview of Abdul Karim [60 years old] member of Tuha Peut Kampung Balai, Samadua, South Aceh).

Here, the principle of reciprocity applies. In simple terms, reciprocity can be interpreted as a reciprocal exchange between individuals or groups. Malinowski introduced this principle based on his research on the Trobriand people. The principle of reciprocity or the principle of reciprocity is a system of donating to create an obligation to retaliate. This principle is the basis that activates people's life. Reciprocity can occur when there is a symmetrical relationship individuals or groups. The symmetrical relationship referred to here is a social relationship, with each of them placing themselves in the same position and role when the exchange process takes place (Abubakar 2007; Malinowski 1960; Sairin 2002). 
At the applicative level, the concept of reciprocity in the celebration of the Prophet Muhammad's birthday among the Aneuk Jamè ethnic group can be seen from the pattern of exchange of invitations. The invited village in the next festivities will act as a host and will invite back the invitee. Here there is an expression of cooperative reciprocity between villages. Each village responded to another village's proposal, which is also an expression of honor to geuchik and other community leaders.

\section{Preparation Time}

Usually, the atmosphere in the village where the maulid is held starts to look crowded one day before the celebration because people who carry out the feast will invite their relatives from other villages to strengthen fraternal relations and strengthen social cohesion. The invitation is intended to assembly family members and relatives who live far apart to celebrate Maulid Nabi and the feast. It is an important moment for the villagers to show togetherness among their family members

From the perspective of invited parties, the invitation is interpreted as an opportunity to help family and relatives, which in normal circumstances cannot be done every time because of the distance of residency. This assistance can be in the form of assets and personal effort. The honor here is that when he comes to fulfill the invitation, the invited person brings sticky rice, coconut, and other useful items in making food in the jamba. Meanwhile, the labor assistance is that they participate in helping the host prepare snacks and everything else that is needed for the maulid celebration (interview of Suami [50 years old] notable women figure of Kampung Balai, Samadua Subdistrict, South Aceh).

Crowds and a festive atmosphere can also be seen in the meunasah or mosque grounds. Men, adults, adolescents, and children, gather and indulge in their respective activities. They set up a stage, arranged the equipment needed for the Liké geleng, installed banners and other accessories, and various other activities to prepare the arena for the peak of the maulid activity, namely Liké geleng. Meanwhile, women are busy with cooking: making cakes, pulut, and other snacks needed, both for the need of their family members and for serving in jamba. The crowd reached its peak on the evening of the Liké geleng batunang performance. People from neighboring villages also flocked to see the Liké geleng.

During this preparation time, it was seen that individuals as members of a community worked together to achieve a common goal, namely the successful implementation of the Liké geleng event. They are immersed in work without being patterned by social status, economic status, and education. It is a manifestation of social cohesion as formulated by The Council of Europe (2004). The estuary of such social phenomena will create social cohesion between individuals in society as indicated by Mubyarto (Mubyarto 1993).

\section{Jamba (Dish)}

In order to serve the attendants of the Liké geleng, the community provided drinks and various cakes. However, the main course is several snacks that are added to the jamba. Jamba is a container made of wood, its functions are to put a tray that has been filled with a 
variety of snacks, in the form of sticky rice and tumpi, side dishes, various cakes, and fruits. Side dishes are usually in the form of tuna baked and stuck in sticky rice, while the typical cake is kareh (Aceh: karah) and other cakes. All the snacks were arranged in stages. There are no special provisions in arranging and arranging snacks into jamba, for example sticky rice must be put on the first level, and so on. Everything is based on the tastes and creations of its constituents.

The size of jamba and dishes that are made are adjusted to the ability to provide containers by each member of the community at the maulid feast. At least, the jamba is made of five levels with a composition of $6 \mathrm{~kg}$ of pulut (sticky rice). However, for those who can afford it, the arrangement of dishes can reach 7 (seven) levels, with the quantity of pulut (sticky rice) reaching $22 \mathrm{~kg}$. The shape of the level resembles a mountain, getting smaller / tapering to the top. In more detail, if the jamba is of a minimum size (6 kg pulut), usually the cakes filled with jamba consist of: 30 sapit cakes, 30 samaloyang, 30 kareh, and 30 sribayung.

During the celebration or maulid feast, each house/family provides one jamba. For some families, considering the limitedness, families are merged; for example, one jamba is provided by two or three households. In principle, all levels of society consciously and voluntarily strive to participate in the maulid feast by providing a jamba intended for guests invited to Liké geleng. A household merger can also be done if the number of guests is less than the number of families holding a feast.

If the village invited comes from within the same sub-district, the inviting party only needs to serve pulut (sticky rice), side dishes and fruits, and arranged in stages in the jamba. If the invited village comes from another sub-district, then pulut and other snacks are not put in the jamba, but served on the table. Here the pulut is wrapped in banana leaves in such a way. Local people call it tungkuih.

Unlike the snacks in jamba, the main menu of the dish at the table is not pulut (although it's still served), but white rice and its side dishes. Each household that provides the containers will put their dishes on the table, which 4-5 people then occupy. If the dish is not finished or is still left over, then the guest will put the rest of the dish into the container provided to take home.

Apart from providing pulut inside the jamba or served in the form of a stove on the table, the host village must also provide another stove to be given to relatives and relatives outside the village, whether invited during the maulid feast or not. Of course, more pulut is destined for family and relatives than is put in jamba or served on the table. For example, suppose the pulut in the jamba or stove on the table consumes $6 \mathrm{~kg}$ of sticky rice. In that case, the tungkuih given to family and relatives outside the village reaches $9 \mathrm{~kg}$ of sticky rice (interview of Suami 50 years old). By using two concepts of cohesion according to Durkheim, organic cohesion and mechanic cohesion, both of its forms could be found in maulid ritual and the preparation of maulid among Aneuk Jamè ethnic group, mechanic cohesion in the form of Muhammad as a central figure in Islam culture, organic cohesion in the form of helping each other, especially among extended family for the dish preparation. 


\section{Peak Event of Liké Geleng}

Liké are verses in Acehnese that contain advice, stories of prophets and friends, events of death, grave punishment, and so on, delivered rhythmically. The variety of rhythms that are served will make like interesting to listen to and follow the lyrics. It is a medium for preaching that is conveyed through art with the intention of warning humans about good and bad, encouraging obedience to Allah, serving and respecting parents, telling the lives of prophets and friends, and so on.

Liké geleng is one of the characteristics displayed at the maulid celebration among the Aneuk Jamè ethnic group. Usually, Liké geleng is performed in a batunang (engaged/reciprocal) group between the host and the guest group, but it is not uncommon for Liké geleng to be performed only by groups from the invited villages or by youths from the village who organize maulid. All of these things had been decided in a village meeting between the geuchik and its residents long in advance. Usually, the duration between the deliberation and the holding of the maulid is up to one month or more, so that the youth have sufficient time to practice. Furthermore, the children passed the nights after the meeting to practice Liké geleng at the mosque.

During this training period, social solidarity and the nature of cooperation as one of the characteristics of the Aneuk Jamè community appeared to emerge. Without waiting for the geuchik's instructions, the community volunteered to donate drinks and cakes or other snacks for the youths who were practicing Liké geleng. To regulate the flow of food and drink to be stable, in the sense that it is not too much on one night and short on another, contributing people are asked to register their names with the geuchik or head of their respective hamlets.

During this period, it was not uncommon for young people to take a dip in the village who were invited to "peek" at the liké rhymes and geleng styles practiced by the youths who practiced in the village. It is done to find liké lyrics and a balanced response to the group of guests later to be great batunang and cannot be defeated by the group of guests.

In this training procession, a sheikh was appointed as the leader. The sheikh plays a role in determining the style of geleng when a liké verse is sung. The sheikh's head shaking and body movements were then followed by other Liké geleng participants simultaneously. In the case of a singular performance, it means not Liké geleng batunang (competition), the shaking of the head and the body movements of the sheikh can easily be followed, because he has practiced before. However, the sheikh's role and creativity are very prominent when the Liké geleng is performed in a batunang manner. He was required to look for a different shake from the one that the guest group had shown in the first session.

Liké geleng is held at night, usually starting at 09.00 PM. If Liké geleng is performed in a batunang manner, the length of time to appear is first agreed upon. Usually, Liké geleng ends at 01.00 AM in the morning. The show starts when the two groups go on stage by stage. The guest group and the host group sit in line by line and face each other. They sat together so that the shoulders of one another in one line collided with one another. One line consists of 12 people. Usually, a group consists of 3 (three) lines, but it 
can be more than that. The number of members between the two groups does not have to be the same. Typically, hosts have a larger liké group than guests.

The first line consists of young people in their 20 s, the second line is more senior than that, and the last line is filled with people aged 40-50 years. The difference in the ages of the people who occupy the line is because one line and another in one group have different head shakes and body movements for one liké and at the same time. The first line has a faster and more dynamic movement than the second line. The last line has a movement that is relatively the same for all the Liké lyrics that are performed, it is just that their main task is to ensure that no sound is interrupted in answering the liké lyrics. Thus, the movements in Liké geleng look very dynamic and are played in a fast rhythm, but still look solid. When compared, it is similar to the speed and cohesiveness of the saman dance movements, but because two groups play Liké geleng, the movements look more dynamic and varied than the saman dance.

Besides that, the two groups were wearing their uniforms. The guest group was allowed to present Nur al-Huda which was quoted from the Dalail al-Khairat book. Next it was the host's turn. After the Nur al-Huda is finished, it is continued by reciting the Qasidah al-Burdah, which is also referred to the Dalail al-Khairat book. Then the process enters the Liké geleng session. The guest group still had the honor of performing the first Liké poems, which were then replied to by the host group. Next, it was the guests' turn, then the host. And so on.
However, this does not mean that the host group is just silent when the guest group brings the liké. They also have to follow the liké lyrics sung by the guest group, but with different body movements and head shakes. Likewise, if the guest group displays a fast and enthusiastic shake, then when it is their turn, the sheikh of the host group must show another movement whose rhythm is no less fast than that of the guest group. Besides, when it is the guest's turn, for example, leading a session, they will bring three slow likés and head shakes and body movements, then speed up regardless of whether the host group can follow it or not. If the homegroup cannot follow it then the home team loses in that session. Likewise, when it is the host's turn to lead the session. Here, the sheikh's role is very decisive, almost similar to that of the sheikh in the Seudati dance.

It is the attraction of Like geleng for the audience. If the two groups can perform in a balanced manner, both in terms of the beauty of the lyrics and rhythm and cohesiveness, the audience will feel very entertained and can last until late into the night. However, if one of the groups "loses" in the batunang, they will feel ashamed. Even though batunang means to compete but in practical terms and real condition, there is no real and stiff competition among the groups; to compete here means only to perform well with more energy, full of enthusiast to show love to Prophet Muhammad. To cover up their embarrassment, they will practice hard to secure the winning in the next meeting, namely during the maulid celebration in the guest group's village.

The success of the implementation of Liké geleng is indicated by the audience's level of 
resistance or endurance to witness the performance. To present Liké geleng that attracts the attention of the audience, each individual in the Liké geleng group must understand each other's roles and maintain group stability and solidity. This condition applies not only between individuals in groups, but also between groups of Liké geleng. Even though each group that appears tries to show its best to outperform other groups, the main purpose of implementing Liké geleng is not to bring down each other between groups, but as a medium of preaching and entertainment the community. However, interaction, cooperation, and social harmony between individuals and groups is prioritized by everyone involved in the implementation of Liké geleng. This is in line with Pelly's view that cooperation between groups in society is an important factor for the development of social cohesion (Anriani et al. 2018).

The development of social cohesion in the implementation of Liké geleng can also be observed using the perspective of Friedkin (2004). It can be seen from the attitude and loyalty shown by each individual to the group, even from the activity preparation period until the implementation of the Liké geleng ends. Every individual is involved for the successful implementation of Liké geleng. This kind of behavior is a reflection of efforts to maintain or strengthen individual membership in the group and an expression of commitment and attachment to the group.

Liké geleng performance ended at around $01.00 \mathrm{AM}$ in the morning, or according to the agreed time. Before the off stage, the two groups closed the show by praying together and being guided by a local cleric. There is something unique and exciting about the Liké geleng stage, namely the verses that are sung in Acehnese so that most listeners and even the poet himself do not know the meaning of the verse. They are only able to understand the meaning of the verse in general. However, because the verses were performed rhythmically and combined with the head shaking and body movements simultaneously and coherently, they were still enthusiastic about watching them.

After the Liké geleng performance ended, the participants from the guest group and the host group were served drinks and various cakes. Furthermore, before the group said goodbye, the geuchik handed over the jamba (dishes) to the group leader to take home. The number of jamba that was handed over was the same as the number of participants of the Liké geleng from the guest group. However, it does not mean that every Liké geleng participant will receive one jamba. Still, the dishes will be distributed to the whole community by the geuchik from the guest group. The distribution was carried out the next day. If jamba contents are distributed, the empty jamba is stored and then returned when the invited village is a guest at the commemoration of Maulid Nabi in their village. Of course, what was returned was not an empty jamba, but had been filled with various snacks as they had been given.

The concept of jamba is the concept of reciprocity, reward for good deeds and good deeds, here good deeds are the willingness of the village who is invited to come and prepare Liké geleng, with all the difficulties, time spent, energy required, invite the village to give and 
give jamba as a way of saying thank you and humble appreciation

\section{Conclusion}

Liké geleng among the Aneuk Jamè ethnic group is an activity to commemorate the birthday of the Prophet Muhammad SAW, it also strengthening brotherly and kinship relations, strengthen social interactions, and strengthen cooperation between communities. All this leads to the strengthening of social cohesion between them. The strengthening of fraternal and kinship relationships is especially shown when a family wants to hold a feast to invite their relatives, especially those who live far apart. They then prepare a dish to put in the jamba as a snack for the Liké geleng participants. The tightening of social interactions can also occur through the holding of the Liké geleng. It happened between residents within one village and between villages, especially between residents of the inviting village and villagers invited to carry out Liké geleng. Collaboration between residents is also strong in organizing the Liké Geleng, both during the preparation period until the evening of the event.

Also, the Liké geleng has activated the tradition of donation among the Aneuk Jamè community. Contributing between the village and families in a kindship relationship is reflected when making various snacks filled in jamba. Contribution among communities between villages is strongly shown in the provision of jamba to people from other villages who were invited. This donation is in line with the principle of reciprocity, whereby the jamba that has been received by the guest group will be returned when they host the next Liké geleng event.
The preparation process and the main event of the Prophet's birthday through the performance of the Liké geleng indeed shows social cohesion between the Aneuk Jamè ethnic group, which is an important event that is celebrated every year, which attracts the attention of the whole community to work together, in the process. working together, everyone accepts the rules and takes full responsibility accordingly; during the Prophet's birthday festival is a moment of strong bonding, caring for each other, and working together for the Aneuk Jamè ethnic group.]

\section{References}

Abdullah, Taufik. 2009. "Di Sekitar Masalah Agama dan Kohesi Sosial: Pengalaman dan Tantangan." Masyarakat \& Budaya 11(1):1-23. doi: 10.14203/jmb.v11i1.232.

Abubakar, Bustami. 2007. "Konsep Fungsi dalam Tradisi Ma'meugang di Aceh." Jurnal Adabiya 8(18):30-37.

Abubakar, Bustami. 2012. "Dinamika Kebudayaan Aceh Pasca Tsunami." pp. 108-13 in Aceh Development International Conference (ADIC) 2012. Kuala Lumpur: International Islamic University Malaysia.

Abubakar, Fauzi. 2016. "Interaksi Islam dengan Budaya Lokal dalam Tradisi Khanduri Maulod pada Masyarakat Aceh." Akademika:Jurnal Pemikiran Islam 21(1):19-34.

Alsair, Ach. Hidayat. 2019. "Mengenal Maudu Lompoa, Tradisi Maulid Akbar di Cikoang Takalar." IDN Time Sulsel. Retrieved (https://sulsel.idntimes.com/news/sulsel /ahmad-hidayat-alsair/mengenal-maudulompoa-tradisi-maulid-akbar-di-cikoangtakalar/3). 
Anriani, Haslinda B., Dahlan Hasan, Harifuddin Halim, and Zainuddin Rasyidah. 2018. "Kearifan Lokal dan Kohesi Sosial dalam Masyarakat Multi Etnik." pp. 37-50 in Prosiding Konferensi Nasional Sosiologi VII. Mataram: Universitas Mataram.

Faisal, Sanapiah. 2003. "Pengumpulan dan Analisis Data dalam Penelitian Kualitatif." in Analisis Data Penelitian Kualitatif: Pemahaman Filosofis dan Metodologis ke Arah Penguasaan Model Aplikasi, edited by B. Bungin. Jakarta: Raja Grafindo Persada.

Fakhrurrazi, Fakhrurrazi. 2012. "Akulturasi Budaya Aceh dan Arab dalam Keunduri Mulod." Forum Ilmu Sosial 39(2):131-42. doi: 10.15294/fis.v39i2.5399.

Fontana, Andrea, and James H. Frey. 1994. "Interviewing: The Art of Science." P. 365 in Handbook of Qualitative Research, edited by N. K. Denzin and Y. S. Lincoln. California: Sage Publications.

Friedkin, Noah E. 2004. "Social Cohesion." Annual Review of Sociology 30(1):409-25. doi: 10.1146/annurev.soc.30.012703.110625.

Hendra, Hendra, Budijanto Budijanto, I. Nyoman Ruja, and M. Iqbal Liayong Pratama. 2019. "Eksistensi Solidaritas Sosial Budaya Maudu Lompoa dalam Tinjauan Geografi Budaya." Jurnal Azimut 2(1):81-94.

Hurgronje, C. S. 1996. Aceh: Rakyat dan Adat Istiadatnya. Jakarta: INIS.

Ibrahim, Muhsinah. 2014. "Dayah, Mesjid, Meunasah sebagai Lembaga Pendidikan dan Lembaga Dakwah di Aceh." Al-Bayan 21(30):21-33. doi: 10.22373/albayan. v20i30.121.

Ismail, Fauzi. 2007. Kedudukan Ulama \& Umara dalam Kehidupan Masyarakat Aceh. Banda Aceh: Ar-Raniry Press.

Jamalie, Zulfa. 2014. "Akulturasi dan Kearifan Lokal dalam Tradisi Baayun Maulid pada Masyarakat Banjar." El-Harakah: Jurnal
Budaya Islam 16(2):234-54. doi: 10.18860/el.v16i2.2778.

Maijar, Andri. 2018. “Tradisi 'Bungo Lado' Sebagai Representasi Budaya Islam di Kabupaten Padang Pariaman." Ekspresi Seni: Jurnal Ilmu Pengetahuan dan Karya Seni 20(2):153-64. doi: 10.26887/ekse.v20i2. 519.

Malinowski, B. 1960. A Scientific Theory of Culture and Other Essays. edited by New York. Oxford University Press.

Manca, Anna Rita. 2014. "Social Cohesion." pp. 6026-28 in Encyclopedia of Quality of Life and Well-Being Research. Dordrecht: Springer Netherlands.

Mubyarto, Mubyarto. 1993. Etos Kerja dan Kohesi Sosial. Yogyakarta: Aditya Media bekerja sama dengan Pusat Penelitian Pembangunan Pedesaan dan Kawasan Universitas Gadjah Mada.

Nadia, Zunly. 2016. "Tradisi Maulid pada Masyarakat Mlangi Yogyakarta." Esensia: Jurnal Ilmu-Ilmu Ushuluddin 12(2):36784. doi: 10.14421/esensia.v12i2.718.

Nurdin, Abidin. 2016. "Integrasi Agama dan Budaya: Kajian tentang Tradisi Maulod dalam Masyarakat Aceh." El-Harakah: Jurnal Budaya Islam 18(1):45-62. doi: 10.18860/el.v18i1.3415.

Reporter. 2019. "Bungo Lado, Sebuah Perayaan Maulid Nabi di Pariaman." Portal Informasi Indonesia. Retrieved (https://indonesia. go.id/ragam/budaya/kebudayaan/bungo -lado-sebuah-perayaan-maulid-nabi-dipariaman).

Sairin, Sjafri. 2002. Pengantar Antropologi Ekonomi. Yogyakarta: Pustaka Pelajar.

Sila, Muhammad Adlin. 2014. "The Festivity of Maulid Nabi in Cikoang, South Sulawesi: Between Remembering and Exaggerating the Spirit of the Prophet." Studia Islamika 8(3):1-56. doi: 10.15408/sdi.v8i3.680. 
Soekanto, Soerjono. 2005. Sosiologi Suatu Pengantar. Jakarta: Rajawali Press.

Sufi, Rusdi, Shabri A, Agus Budi Wibowo, Irini Dewi Wanti, Elly Widarni, Djuniat, Seno, Irvan Setiawan, and Sri Wahyuni. 1998. Keanekaragaman Suku dan Budaya di Aceh. Banda Aceh: Balai Kajian Sejarah dan Nilai Tradisional.

Suprayogo, Imam, and Tobroni. 2001. Metodologi Penelitian Sosial Agama. Bandung: Remaja Rosdakarya.

The Council of Europe. 2004. "A New Strategy for Social Cohesion." Retrieved (https://www. coe.int/t/dg3/socialpolicies/socialcohesio ndev/source/RevisedStrategy_en.pdf).

Yuliana, Yuliana, and Soedarsono Soedarsono. 2004. "Perayaan Maudu' Lompoa: Sebuah Peristiwa Ritual Agama di Cikoang Takalar Sulawesi Selatan." Universitas Gadjah Mada.

Zainuddin, Muslim. 2007. "Syari'at Islam di Aceh dalam Dimensi Sosiologis." in Pergulatan Panjang Budaya Damai dalam Masyarakat Multikultural, edited by M. N. Budiman. Banda Aceh: Ar-Raniry Press. 
This page has been intentionally left balnk. 